\title{
THE REASONS OF THE CONFLICT \\ BETWEEN THE CHURCH AUTHORITIES OF CHERSON, SOUGDEA-FOUL, GOTHIAN METROPOLIES FOR THE PARISHES OF THE SOUTHERN COAST OF THE CRIMEA (SECOND HALF OF THE $14^{\text {TH }}$ CENTURY) ${ }^{1}$
}

\author{
Sergey G. Bocharov \\ Institute of Archaeology of Crimea, RAS, Simferopol, Russian Federation
}

\begin{abstract}
The article reviews the conflict that took place in the second half of the $14^{\text {th }}$ century in the territory of the Mountain Crimea between the metropolitan of Cherson, on the one hand, and the metropolitans of Gothian and Sougdea-Foul for the domination in two ecclesiastical districts of Eliss and Kinsanus. The historical outline of events is preserved in five acts of the Patriarchate of Constantinople from 1382 to 1390. These districts are localized on the territory of the Southern Coast of Crimea, from the village Nikita in the west to the village Kanaka (actual Lutch) in the east, they bordered each other in the Alushta area. The research showed, that the movement of the Orthodox population within the territories of different metropolitanates influenced the fact, that in the middle of the $14^{\text {th }}$ century the oldest, once the richest and most populated diocese in the Crimea, comes to desolation. The city of Chersonesus disappears as a large city and a significant regional center. Capture of tow parish districts by Cherson's hierarchs became possible for two reasons. The first reason is the changes in political borders in this region. After almost a thousand years domination of the Byzantine Empire in the middle of the $13^{\text {th }}$ century the Southern Coast of Crimea with the Byzantine (Greek) agricultural population pass under the jurisdiction of the Mongolian state. Later, in the second half of the $14^{\text {th }}$ century a new process begins - the transition of the coastal territories of the Mountain Crimea from the Golden Horde to the Genoese State, which finishes in 1387. The second reason is the patronage of Cherson metropolitans from new Genoese authorities, with support of the emperors Andronicus IV and John VII Paleologues, loyal to the Genoese, and their protege Macarius, Patriarch of Constantinople.

Key words: Byzantinum, Republic of Genoa, Golden Horde, commune of Caffa, Mountain Crimea, Metropolies of Cherson, Gothia, Sougdea-Foul, districts of Eliss and Kinsanus.

Citation. Bocharov S.G. The Reasons of the Conflict Between the Church Authorities of Cherson, Sougdeafoul, Gothian Metropolies for the Parishes of the Southern Coast of the Crimea (Second Half of the $14^{\text {th }}$ Century). Vestnik Volgogradskogo gosudarstvennogo universiteta. Seriya 4, Istoriya. Regionovedenie. Mezhdunarodnye otnosheniya [Science Journal of Volgograd State University. History. Area Studies. International Relations], 2017, vol. 22, no. 5, pp. $46-55$ (in Russian). DOI: https://doi.org/10.15688/jvolsu4.2017.5.5
\end{abstract}

\section{О ПРИЧИНАХ КОНФЛИКТА МЕЖДУ ИЕРАРХАМИ ХЕРСОНСКОЙ, СУГДЕЙСКО-ФУЛЬСКОЙ И ГОТСКОЙ МИТРОПОЛИЙ ЗА ПРИХОДЫ ЮЖНОГО БЕРЕГА КРЫМА (ВТОРАЯ ПОЛОВИНА ХІV в.) ${ }^{1}$}

\author{
Сергей Геннадиевич Бочаров \\ Институт археологии Крыма РАН, г. Симферополь, Российская Федерация
}

Аннотация. В статье рассматривается конфликт, происходивший во второй половине XIV в. на территории Горного Крыма между митрополитом Херсонским с одной стороны и митрополитами Готским и Суг- 
дейско-Фульским - с другой, боровшимися за владение двумя церковными округами Элисс и Кинсанус на территории Горного Крыма. Историческая канва событий содержится в пяти актах Константинопольского Патриарха за 1382-1390 годы. Эти округа удалось локализовать на территории Южного берега Крыма, от селения Никита на западе до селения Канака (совр. Луч) на востоке, граничили они друг с другом в районе западнее Алушты. Исследование показало, что перемещение православного населения в границах различных митрополий привело к тому, что к середине XIV в. самая старейшая, некогда богатейшая и наиболее населенная епархия в Крыму - Херсонская приходит в запустение, Херсонес теряет статус крупного города и значительного регионального центра. Захват Херсонскими иерархами новых округов стал возможен в силу двух причин. Первая причина - изменение политических границ в этом регионе. После почти тысячелетнего вхождения в Византийскую империю в середине XIII в. Южный берег Крыма с ромейским (греческим) земледельческим населением переходит под юрисдикцию монгольского государства. Затем, во второй половине XIV в., начинается новый процесс - переход приморских территорий Горного Крыма от Золотой Орды к Генуэзскому государству, который закончится в 1387 году. Вторая причина - покровительство Херсонским митрополитам со стороны новых генуэзских властей при одобрении лояльных к генуэзцам императоров Андроника IV и Иоанна VII Палеологов и их ставленника - константинопольского патриарха Макария.

Ключевые слова: Византия; Генуэзская республика; Золотая Орда; коммуна Каффы; Горный Крым; митрополии Херсонская, Готская и Сугдейско-Фулльская; округа Элисс и Кинсанус.

Цитирование. Бочаров С. Г. О причинах конфликта между иерархами Херсонской, Сугдейско-Фульской и Готской митрополий за приходы южного берега Крыма (вторая половина XIV в.) // Вестник Волгоградского государственного университета. Серия 4, История. Регионоведение. Международные отношения. - 2017. T. 22, № 5. - C. 46-55. - DOI: https://doi.org/10.15688/jvolsu4.2017.5.5

Письменные источники XIII-XV вв. очень кратко и отрывочно упоминают византийские земли Южного берега Крыма, на которых находились деревни греческого (ромейского) православного населения. Поэтому становится понятным интерес исследователей к этим единичным свидетельствам о регионе, которые в силу своей эпизодичности и краткости вызывают совершенно разные толкования. В средневековой Таврике (Крыму) в интересующий нас период размещались четыре митрополии византийской церкви: Херсонская, Боспорская, Готская и Сугдейско-Фульская [4, с. 129-135]. Статья посвящена событиям, нашедшим отражение в пяти актах Константинопольского Патриархата (CCCLV 1382 г., CCCLXVII - 1384 г., CCCLXVIII 1385 г., CCCLXX - 1386 г., CCCCXIX - 1390 г.) $[28$, s. 489-491; 2, c. 458-462, 464-466, 467469; 26, p. 89-92, 169]. В эти события были вовлечены три из четырех высших таврических священников, а арбитром в их споре был сам патриарх. В документах освещается конфликт, который был вынесен на самый высокий церковный суд - синодальный и рассматривался в течение правления трех патриархов. Суть конфликта заключалась в попытках захвата митрополитом Херсонским в период с 1364 по 1390 г. [2, с. 459, 468] двух приморских приходских округов - Кинсанус

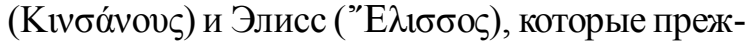
де принадлежали двум митрополиям - Готской и Сугдейско-Фульской соответственно.

К теме спора церковных иерархов обращались многие исследователи крымского средневековья, как правило, просто описывая сами события, отмечая бедственное положение Херсонской митрополии и констатируя действия по расширению зоны сбора каноникона $[4$, с. $56-64 ; 16$, с. $115-116 ; 23$, с. $41 ; 14$, c. $79-80 ; 21$, c. $187 ; 5$, c. $109 ; 3$, c. $71-73 ; 19$, c. 146]. О причинах этого спора были выдвинуты две основные гипотезы. Первая очень важная и продуктивная, объясняющая положение в Кинсанусе, но оставляющая без внимания ситуацию с Элиссом: «гораздо большее значение здесь имело политическое изменение положения страны, разорвавшее Готскую епархию на две части; северная, за горами, осталась вместе с Феодоро независимым владением, а южный берег захватили генуэзцы, и как бы ни были они осторожны с инославными, но одному Готскому сообразоваться с двумя различными правительствами по новости дела было трудно» [4, c. 64]. Вторая версия оригинальна, но вряд ли отвечает реальности - основными интересантами захвата округов Элисс и Кинсанус были «торгово-ремесленные слои горожан и крупные землевладельцы города», на- 
правляющие действия Херсонских митрополитов [21, с. 187].

В «чужие» округа Элисс и Кинсанус священнослужители Херсонской митрополии пытались проникнуть в правление патриарха Филофея (1364-1376 гг.) (о его правлении см.: [17, c. 213-219]). Эти попытки были решительно остановлены специальной патриаршей грамотой, текст которой до нас не дошел, но отсылки к ней есть в изучаемых документах [2, с. 459]. Несмотря на, казалось бы, своевременно пресеченный конфликт, уже следующий патриарх Макарий (1376-1379 гг.) (о его правлении см.: $[18$, c. $161 ; 17$, с. 219]) дарует митрополиту Херсонскому синодальный акт на право владеть округами Элисс и Кинсанус и собирать с них каноникон [2, с. 458, 468].

Конфликт получил дальнейшее продолжение. Вернуть отобранные у них округа и восстановить свои законные права иерархи Сугдейско-Фульский и Готский пытаются при следующем патриархе Ниле (1379-1388 гг.) (о его правлении см.: [17, с. 219-221]). Понимая совершенную законность требований двух иерархов («...та грамота несправедлива, не имеет более действия и силы, как составленная незаконно и неправильно» ${ }^{2}$ [2, с. 458], «грамота отрезает большую часть святейшей митрополии Готфийской, да отрывает другую не малую часть от Сугдейской, и прикладывает к Херсонской церкви» [2, с. 464]), с одной стороны, Нил отменяет постановление Макария, а с другой - патриарх принимает странное и половинчатое решение. Округ Элисс он возвращает Сугдейско-Фульской митрополии, Кинсанус же, напротив, оставляет митрополиту Херсонскому, заручившись на это согласием Готского иерарха, с условием забрать округ Кинсанус из-под юрисдикции Херсонского митрополита в случае расширения его претензий на иные территории и селения Готской епархии [2, с. 462]. Далее события развиваются в совершенно непредсказуемом направлении. Макарий в 1390 г. во время своего второго краткого возвращения на патриарший престол повторно категорически и безапелляционно отдает округа Кинсанус и Элисс во владение митрополии Херсонской, фактически возобновляет свой собственный акт, отмененный патриархом Нилом [2, с. $467-$ 469]. Непонятно, как стала возможной столь несправедливая ситуация, противоречащая одному из основных церковных правил, сформулированному в патриаршей грамоте 1382 г.: «Ибо священными правилами определено, чтобы приходы каждой епархии и епископии были неотъемлемы, особенно если есть уже тридцатилетнее владение. Если мы допустим, чтобы отнималось от одной епархии и придавалось другой, тогда все пойдет вверх дном, на разрушение древнего установления, все наполнится беспорядком и смятением, великое дело мира и единомыслия исчезнет, и братоненавидение войдет между архиереев, учителей мира» [2, с. 458].

Разбирая причины возникновения данного конфликта, надо ответить на два основных вопроса: каким образом стали возможны претензии митрополита Херсонского, несмотря на четкие правила владения церковными землями, и где, собственно, локализуются спорные территории, насколько удалены или приближены они к границам его митрополии.

Первый вопрос, на который необходимо найти ответ: почему, игнорируя определенную священными правилами норму: «чтобы приходы каждой епархии были неотъемлемы, особенно если есть уже тридцатилетние владение», митрополит Херсонский стал отнимать округа, расположенные на значительном расстоянии от границ его диоцеза? По нашему мнению, ответ следует искать в политической ситуации, сложившийся на Южнобережье в это время. И как следствие, в изменении политических границ в исследуемом регионе в последней трети XIV в., которое, в свою очередь, сделало возможным пересмотр церковных границ.

После почти тысячелетнего вхождения в Византийскую империю в середине XIII в. Южный берег Крыма с ромейским (греческим) земледельческим населением переходит под юрисдикцию монгольского государства [8, c. 810-811]. Попав в состав новой Монгольской империи, селения земледельческой округи Сугдеи, Херсонеса и Южнобережья продолжали сохранять традиционную, оставшуюся от Византии схему местного самоуправления [11, с. 192; 13], неизменной осталась и церковная организация, регион Горного Крыма (Таврики) продолжал входить в три митрополии Константинопольского патриархата: 
Готскую, Херсонскую, Сугдейско-Фульскую $[4$, c. $35-53]$.

Во второй половине XIV в. начинается новый процесс - переход интересующих нас приморских территорий Горного Крыма от Золотой Орды к Генуэзскому государству, который в конечном итоге займет около сорока лет. В 1344 г. в административном центре Готии (caput Gotie) городе Чембало (современная Балаклава) упоминается генуэзский нотарий, что свидетельствует о наличии здесь небольшого торгового поселения - фактории [24, p. 157]. Первое упоминание о генуэзском официале - консуле в Чембало относится к $1347-$ 1349 гг. [15, с. 39]. Уже в 1357 г. есть известие о строительстве каменных крепостных сооружений в городе консулом Симоне дель Орто $[29$, р. $129 ; 1$, с. $12-18]$. Одновременно с захватом в 1365 г. Солдайи и ее сельской округи из 18 деревень [9, с. 292], видимо, были при- соединены к генуэзскому домену и селения Южнобережья. De facto чиновники, направленные из Каффы, уже в 1374 г. проводят инспекцию селений Готии с целью ревизии населения и определения всего спектра пунктов налогообложения для побережья [24, p. 160]. De jure это положение было закреплено договором от 27 ноября 1380 г., которым территории Южного берега Крыма (ripparia marina Gotia) были выведены из протектората Золотой Орды и официально перешли под власть коммуны Каффы [11, с. 186].

В соответствии с этим договором, генуэзским властям, помимо города Чембало с сельской округой, передан город Солдайя с восемнадцатью селениями (cazallium Soldaya) (см. рисунок): Сохіi (Солнечная Долина Козы), Sancti Johannis (Солнечногорское Куру-Узень), Tarataxii (долина Ай-Ван), Louolli (Ворон), Sille (Громовка - Шелень), Sdaffo (Co-

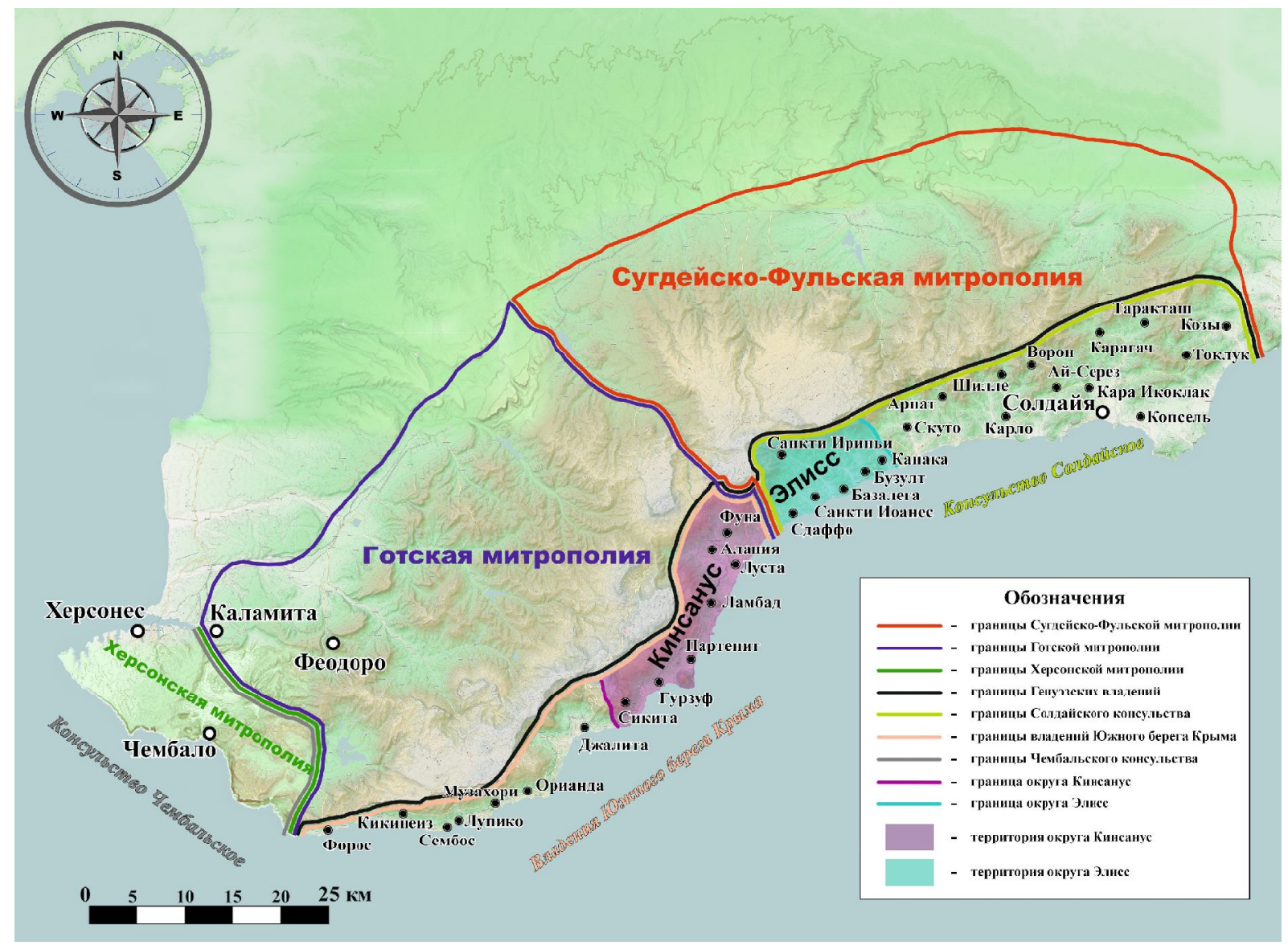

Карта южной части Крымского полуострова с нанесением границ митрополий

Константинопольского патриархата, генуэзских владений и церковных округов Элисс и Кинсанус

Map of the southern part of the Crimean peninsula with the imposition of the boundaries of the metropolies of the Patriarchate of Constantinople, the Genoese possessions and the church districts of Eliss and Kinsanus 
тера), Canecha (Канака), Carpati (Зеленогорье - Арпат), Scuto (Приветное - Ускут), Bazalega (Малореченское - Кучук-Узень), Buzult (Рыбачье - Туак), Cara ihoclac (Beceлое - Кутлак), Diauollo (Копсель), Carlo (Mopское - Капсихор), Sancti Erigni (Генеральское Улу-Узень), Saragaihi (Карагач), Paradixii (Богатовка - Токлук), Cheder (Междуречье - АйСерез) [9, с. 286-291], а также селения прибрежной Готии (cazallis Gotia): Fori (Форос), Chinicheo (Кикенеиз), Lupico (Алупка), Muzacori (Мисхор), Orianda (Ореанда), Jallita (Ялта), Sikita (Никита), Gorzouium (Гурзуф), Partenite (Партенит), Lambadie (Кучук - Ламбат), Lusta (Алушта), Fomia (Фуна) [11, с. 191; 10, c. 207].

Финалом длительного ордынско-каффийского противостояния стали события Солхатской войны 1385-1386 гг. [25, p. 15]. Греки побережья в этом конфликте принимают сторону ордынцев. В 1386 г. население Готии восстает против новых владетелей, на подавление этого восстания из Каффы был послан военный корабль [24, p. 161]. Мирный договор, заключенный 12 августа 1387 г., положил юридическое окончание Солхатской войне. Среди прочих пунктов, были закреплены права коммуны Генуи на все ранее захваченные в Крыму территории, в том числе и селения сельской округи Солдайи и Южного берега Крыма [12, с. 265]. Отметим для себя важный для нашего исследования момент: приморские территории Горного Крыма за чуть более чем вековой период, условно с середины XIII в. до середины XIV в., трижды поменяли политическую принадлежность от Византийской империи к империи Монгольской, а затем оказались во владениях коммуны Каффы Генуэзской республики.

Второй вопрос, требующий ответа, при поиске причин рассматриваемого нами церковного конфликта - определить и локализовать территории, которые занимали оспариваемые округа. Возможно, они всегда были пограничными и спорными территориями между Херсонским с одной стороны и Готским и Сугдейско-Фульским митрополитами с другой стороны? Селения, которые составляли Кинсанус, указаны в двух актах. В акте CCCLXVII 1384 г. перечислены Алания, Фуна, Алушта, Лампада, Парфенита и Сикита [2, c. 460]. Акт CCCCXIX 1390 г. упоминает то-

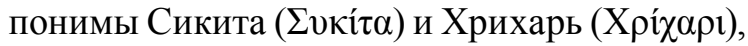

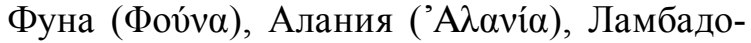
Парфенита $(\Lambda \alpha \mu \pi \alpha \delta$ о $\alpha \rho \rho \theta \varepsilon v i ́ \tau \alpha)$ и Алушта

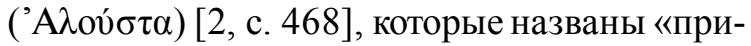
брежными местами» [2, с. 468]. Следовательно, округ Кинсанос примыкал к морю. Большинство указанных в этих двух актах названий легко узнаваемы и перекликаются с топонимами, упомянутыми в генуэзских документах [13, с. 109]. Большинство из них понятны: Фуна - Лучистое - Демерджи, Алушта, Лампада - Малый Маяк - Биюк-Ламбад, Партенит, Сикита - Никита (см. рисунок). В отдельном комментарии нуждаются названия Алания и Хрихарь. По нашему мнению, судя по порядку их упоминаний среди других селений Южнобережья, Алания - это селение, позднее известное как Изобильное - Корбеклы (которое точно определил А.Л. Бертье-Делагард $[4$, с. 12]), а как Хрихарь (восточнее Никиты и западнее Паренита) записан Гурзуф - Гурзувиум (по А.Л. Бертье-Делагарду селение Хрихарь слилось с Сикитой, которую он отождествляет с деревней Запрудное - Дегерменкой - Миляри [4, с. 5]). В целом не вызывает сомнения, что округ Кинсанус находился в восточной части Южного берега Крыма и приблизительно охватывал территорию протяженностью около 23 км от современного поселка Никита до Алушты (см. рисунок). А.Л. Бертье-Делагард был близок к правильному размещению этого округа, но ошибочно ограничил его западную границу Партенитом и горой Аю-Даг [4, с. 5, карта].

В церковных документах входившие в Элисс селения по отдельности не названы, и определить точные границы этого округа мы можем гипотетически. При локализации Элисса необходимо учитывать, что два интересующих нас церковных округа граничили друг с другом и Элисс назван пограничным относительно земель Сугдейско-Фульской митрополии [2, с. 469], то есть граничил с Готской. Единственное место, где две митрополии граничили друг с другом, - это район восточнее Алушты. К западу от Кинсануса находились земли, принадлежавшие этой же Готской митрополии. Следовательно, Элисс располагался восточнее Кинсануса и к западу по побережью от епархиального центра Сугдеи - Сол- 
дайи. По нашему мнению, этот округ занимал самую западную часть исторической сельской округи Сугдеи, где он граничил с землями Готской митрополии. В современной географической номенклатуре это двадцатикилометровый участок побережья Юго-Восточного Крыма с населенными пунктами дистрики Солдайи от селения Сдафо (Сотера) на западе до селения Канака (Челмекчи, современное Луч) на востоке. Территорию округа в целом правильно определил А.Л. Бертье-Делагард $[4$, с. 5 , карта] (но ученый не включил в него селение Канака и завершил территорию округа у деревни Туак, что, по нашему мнению, не верно). Округ Элисс мог состоять из примерно такого же количества деревень, как и округ Кинсанус. В него входили селения Сдафо - Сотера, Санкти Иоанес - Солнечногорское - Куру-Узень, Санкти Ириньи - Генеральское - Улу-Узень, Базалега - Малореченское - Кучук-Узень, Деспитра - Рыбачье Туак, Канака - Челмекчи (см. рисунок).

При взгляде на карту (см. рисунок) становится понятно, что богатые приходы Южнобережья располагались далеко от границ Херсонской митрополии и не могли быть спорными по пограничному принципу, а Сугдейско-Фулльская митрополия вообще не имела общей границы с митрополией Херсонской. Скорее всего, Херсонских иерархов привлекли территории с большим количеством сельских жителей, находящиеся на значительном расстоянии от границ их владений. О количестве населения этих мест в нашем распоряжении нет источников конца XIV века. Но о нем можно судить по более поздним данным османской переписи населения 20-х гг. XVI века. Так, по самым приблизительным подсчетам, количество семей деревень округа Элисс составляло в Сдафо (Сотера) - 42, Санкти Иоанес (Куру-Узень) - 72, Санкти Ириньи (Улу-Узень) - 45, Базалега (КучукУзень) - 44, Деспитра (Туак) - 12, Канака - 9. Всего 224 очага [30, p. 244, tab. III]. В округе Кинсанус эти цифры еще выше: Фуна (Демерджи) - 56, Алания (Крбеклы) - 31, Алушта 148, Лампада (Биюк-Ламбад) - 73, Партенит - 114, Хрихарь (Гурзуф) - 150, Сикита (Никита) - 38. Всего - 610 очагов [27, p. 164-165; 29 , p. 245, tab. III]. Боле того, селения Алушта, Гурзуф, Партенит, Куру-Узень, Биюк-Лам- бад и Демерджи входят в двадцатку самых населенных пунктов османского Крыма [27, p. 167]. Для сравнения, деревни сельской округи Херсонеса исчезают полностью, а сам город превращается к 40-м гг. XVI в. в неукрепленный пункт Сары-Кермен [30, p. 245, tab. III].

Подводя итоги исследования причин конфликта между главой митрополий Херсонской с главами митрополий Готской и СугдейскоФулльской из-за двух прибрежных церковных округов Кинсанус и Элисс, выделим основные заключительные пункты.

Изменение политической ситуации в Крыму и перемещение православного населения в границах различных митрополий (начинается этот процесс с появлением монголов [22, с. 26], его завершающую стадию отмечает акт XLI [2, с. 445-446]) привело к тому, что к середине XIV в. самая старейшая, высшая в ранге росписей Константинопольского престола [4, с. 128], некогда богатейшая и наиболее населенная епархия в Крыму, по определению митрополита Нила, стала «бедна, находится без средств и в нужде» [2, с. 458]. Упадок Херсонской митрополии иллюстрирует случай, когда с епископа бралось письменное обещание прибыть в Крым и возглавить эту митрополию [2, с. 446]. Еще одно свидетельство этого упадка - временное возложение управления в 1368 г. на митрополита соседней епархии Готии в связи с отсутствием настоятеля и явного нежелания византийских иерархов возглавлять кафедру митрополии Херсонской [2, с. 457-458]. Херсонес исчезает как крупный город и значительный региональный центр [23, с. 42], население его сельской округи, скорее всего, переселяется ближе к активно развивающимся поствизантийским городским центрам, которые находились в Горной части Юго-Восточного Крыма на территории Готской митрополии. Эти территории в начале XV в. послужат ядром образования княжества Феодоро, одноименная столица которого станет резиденцией Готского митрополита, титулатура которого будет звучать: «митрополит города Феодоро и всей Готии» $[19$, с. 143$]$. Готская митрополия станет идеологическим стержнем нового греческого княжества [20, с. 189].

В середине XIV в. в границах Херсонской митрополии активно развивается новый 


\section{ВИЗАНТИЙСКАЯ ТАВРИКА}

город Чембало, именуемый «глава Готии», а иерархи Херсонские (используя новые политические реалии) пытаются и в конечном итоге добиваются расширения своих владений за счет переподчиненной коммуне Каффы приморской Готии (cazallis Gotia) и сельской округи Солдайи (cazallium Soldaya) [7, с. 59]. При этом главы клира Херсонской митрополии удачно используют в своих интересах смену политических границ и изменение статуса прибрежных территорий от Чембало до Солдайи $[6$, с. 109] в качестве новых владений Генуэзской республики.

Необходимо обратить внимание на тот факт, что легализует захваты территорий прибрежных приходов Элисс и Кинсанус, несмотря на их полное несоответствие всем установленным положениям и церковным нормам, патриарх-латинофил Макарий [18, с. 172], ставленник особо благоволивших генуэзцам византийских императоров Андроника IV и Иоанна VII Палеологов [18, с. 172-173]. Такие действия Херсонских иерархов, противоречащие базовым церковным уложениям, касающимся правил владения приходами, могли проводиться только при попустительстве или даже при прямой поддержке латинских официалов Каффы.

Как следует из акта CCCLXX 1386 г., митрополит Херсонский распространял свои притязания не только на Кинсанус, но и на все южнобережные земли Готской митрополии: «...чтобы он все-таки владел одним Кинсанусом с окрестными деревнями, от прочего же совершенно отказался и никогда его не требовал; в противном же случае, при самом малом соблазне с его стороны, у него и Кинсанус возьмет Готфский, как свой собственный приход», «...опять начал смущение, намереваясь и прочее взять у Готфского», «...повелевается: Херсонскому иметь один только Кинсанус с окрестными деревнями и ничего более, а все прочее, что там есть, иметь Готфскому безмятежно, непоколебимо, неотъемлемо и неразрывно, как принадлежащее его церкви и состоящее в его епархии, и если отселе Херсонский успокоится, и отстанет он прежних соблазнов и смущения, хорошо. Если же и еще будет делать тоже самое, и возбудить самомалейший соблазн, или напишет к нашей мерности вопия, что он обижен, и требуя опять того же, то окончательно потеряет и то, что теперь имеет, а Готфский получит и Кинсанус и все, что вокруг него, соответственно бывшему на месте исследованию, и будет владеть им на правах своего прихода, с неотъемлемым владением и господством» $[2$, c. 458-459]. Патриарх Нил в свою очередь стремился ограничить эти притязания и свести их к владению только одним округом Кинсанус, поскольку они распространялись на всю территорию Готской митрополии, оказавшуюся в управлении генуэзцев.

Возможно, поддержкой этих действий генуэзская администрация Каффы пыталась влиять не только административно на население новоприсоединенных территорий, но также контролировать через более лояльных Херсонских иерархов и религиозную жизнь. Понятно, что генуэзцев более устраивали митрополиты Херсонские, располагавшиеся в Херсонесе, а затем в близлежащем на мысу Фиолент монастыре св. Георгия, на территориях, подконтрольных Генуе в окрестностях Чембало, чем практически независимые Готские иерархи.

После захвата генуэзских владений на Крымском полуострове в новых политических реалиях османского Крыма угасшая Херсонская митрополия будет ликвидирована в XVII в. и земли, в нее входившие, будут присоединены к ближайшей соседней Готской митрополии [4, c. 132], а затем упоминания о ней вовсе исчезнут из исторических источников.

\section{ПРИМЕЧАНИЯ}

${ }^{1}$ Исследование выполнено за счет гранта Российского научного фонда (проект №14-2800213).

2 Здесь и далее сохранены орфография и пунктуация источника.

\section{СПИСОК ЛИТЕРАТУРЫ}

1. Адаксина, С. Б. Формирование малых городов Генуэзской Газарии (на примере фактории в Чембало: 1345 - 1476 гг.) / С. Б. Адаксина, В. Л. Мыц // Таврические Студии. Исторические науки. 2015. - № 7. - C. 12-18

2. Антонин (архимандрит). Древние акты Константинопольского патриархата, относящиеся к Новороссийскому краю / архимандрит Антонин // Записки Одесского общества истории и древностей. - 1866. - T. VI. - С. 445-474. 
3. Байер, Г.-В. Метрополии Херсона, Сугдеи, Готии и Зихии по данным просопографического лексикона времени Палеологов / Г.-В. Байер // Античная древность и Средние века. - 1995. - Вып. 27. C. $65-76$.

4. Бертье-Делагард, А. Л. Исследование некоторых недоуменных вопросов средневековья в Тавриде / А. Л. Бертье-Делагард // Известия Таврической ученой архивной комиссии. - 1920. - № 57. C. $1-136$.

5. Богданова, Н. М. Херсон в X - XV вв. Проблемы истории византийского города / Н. М. Богданова // Причерноморье в Средние века. Вып. 1 / отв. ред. С. П. Карпов. - М. : МГУ, 1991. - С. 8-172.

6. Бочаров, С. Г. Археологические исследования средневекового замка Гелин-Кая в 2006 году / С. Г. Бочаров // Актуальные вопросы археологии Поволжья. К 65-летию студенческого археологического кружка Казанского университета / отв. ред. Д. А. Сташенков. - Казань : ИИ АН РТ, 2012. C. 109-121.

7. Бочаров, С. Г. Археология Латинской Газарии: определение термина и научное содержание / С. Г. Бочаров // Труды III Международного конгресса средневековой археологии евразийских степей «Между Востоком и Западном: движение культур, технологий и империй» / отв. ред. Н. Н. Крадин, А. Г. Ситдиков. - Владивосток : Дальнаука, 2017. -C. 57-63.

8. Бочаров, С. Г. Генуэзские владения в Крыму во второй половине XIV в. / С. Г. Бочаров // Былые годы (Bylye Gody). - 2015. - № 38-1. C. 808-824.

9. Бочаров, С. Г. Заметки по исторической географии Генуэзской Газарии XIV-XV веков. Консульство Солдайское / С. Г. Бочаров // Античная древность и средние века. - 2005. - № 36. - С. 282-294.

10. Бочаров, С. Г. Заметки по исторической географии генуэзской Газарии XIV-XV. Консульство Чембальское / С. Г. Бочаров // Поволжская археология. -2017. - № 2. - С. 204-223.

11. Бочаров, С. Г. Заметки по исторической географии Генуэзской Газарии XIV-XV вв. Южный берег Крыма / С. Г. Бочаров // О древностях Южного берега Крыма и гор Таврических : сб. науч. тр. по материалам конф. в честь 210-летия со дня рождения П. И. Кеппена / отв. ред. В. Л. Мыц. - Киев : Стилос, 2004. - С. 186-205.

12. Бочаров, С. Г. Историческая география Генуэзской Газарии / С. Г. Бочаров // Диалог городской и степной культур на Евразийском пространстве. Историческая география Золотой Орды : материалы VII Междунар. конф., посвящ. памяти Г. А. Федорова-Давыдова / отв. ред. С. Г. Бочаров, А. Г. Ситдиков. - Кишинев : Stratum plus, 2016. C. 263-269.
13. Бочаров, С. Г. Предварительные результаты археологического исследования укрепления Учансу-Исар / С. Г. Бочаров // Взаимоотношения Северного и Западного Причерноморья в античную эпоху и средневековье / отв. ред. С. Г. Бочаров, В. Кожокару. - Симферополь : Изд-во Барановского, 2009. - С. 108-114.

14. Веймарн, Е. В. О двух неясных вопросах средневековья юго-западного Крыма / Е. В. Веймарн // Археологические исследования средневекового Крыма / отв. ред. О. И. Домбровский. - Киев : Наукова думка, 1968. - С. 45-82

15. Карпов, С. П. Итальянские морские республики и Золотая Орда. Кризис 1343-1349 гг. / С. П. Карпов // Причерноморье в средние века. Вып. 9. / отв. ред. С. П. Карпов. - СПб. : Алетейя, 2015. - C. 7-42.

16. Кулаковский, Ю. А. Прошлое Тавриды. Краткий исторический очерк / Ю. А. Кулаковский. Киев : Изд-во В. И. Кульженко, 1914. - 154 с.

17. Лебедев, А. П. Исторические очерки состояния Византийско-восточной церкви от конца XI до середины XV века / А. П. Лебедев. - СПб. : Алетейя, 1998. $-383 \mathrm{c}$.

18. Мейендорф, И. (прот.) Византия и Московская Русь: очерк по истории церковных и культурных связей в XIV веке / прот. И. Мейендорф. - Paris : YMCA-PRESS, 1990. $-227 \mathrm{c}$.

19. Мыц, В. Л. Каффа и Феодоро в XV веке. Контакты и конфликты / В. Л. Мыц. - Симферополь : Универсум, 2009. - 528 с.

20. Мыц, В. Л. Несколько заметок по эпиграфике средневекового Крыма / В. Л. Мыц // Византийская Таврика / отв. ред. П. П. Толочко. - Киев : Наукова думка, 1991. - С. 179-193

21. Романчук, А. И. Херсонес XII-XIV вв. Историческая топография / А. И. Романчук. - Красноярск : Изд-во Краснояр. ун-та. 1986. - 192 с.

22. Тизенгаузен, В. Г. Сборник материалов, относящихся к истории Золотой Орды / В. Г. Тизенгаузен. - СПб. : Изд-во Имп. Акад. наук, 1884. - Т. 1.$559 \mathrm{c}$.

23. Якобсон, А. Л. Средневековый Херсонес (XII-XIV вв.) / А. Л. Якобсон. - М. ; Л. : АН СССР, $1950 .-255 \mathrm{c}$.

24. Balard, M. La Romanie Génoise (XIIe-début du XV e siècle) / M. Balard. - Roma, Genova: École Française de Rome, 1978. - T. 1. - 494 p.

25. Basso, E. Il "bellum de Sorchati" ed i trattati del 1380-1387 tra Genova e l'Ordo d'Oro / E. Basso // Studi genuensi. Nova Seria. - 1991. - Vol. VIII. - P. 11-26.

26. Darrouzès, J. Les regestes des actes du Patriarcat de Constantinople. Les actes de Patriarches. Las regestes de 1377 a 1410 / J. Darrouzés. - Paris : Institut français d'études byzantines, 1979. - Vol. I. Fasc. VI. -548 p. 
27. Fisher, A. The Ottoman Crimea in Sixteenth Century / A. Fisher // Harvard Ukrainian Studies. 1981. - Vol. V, № 2. - P. 135-170.

28. Miklosich, F. Acta et diplomata graeca medii aevi sacra et profana / F. Miklosich, J. Müller. Vindobonae : Carolus Gerold, 1860. - T. I. -543 p.

29. Skrzinska, E. 1928. Inscriptions latines des colonies génoises en Crimée / E. Skrzinska. - Genova : Atti della Societa Ligure di Storia Patria, 1928. Vol. LV1.-141 p.

30. Veinstein, G. La population du Sud de la Crimée au début de la domination Ottomane / G. Veinstein // Bulletin de Institut français d'études anatoliennes. Mémorial Ömer Lûtfi Barkan. - 1980. - Fis. XXVIII. P. 227-249.

\section{REFERENCES}

1. Adaksina S.B., Myts V.L. Formirovanie malykh gorodov Genuezskoy Gazarii (na primere faktorii v Chembalo: 1345 - 1476 gg.) [Formation of Small Towns of the Genoese Gazaria (on the Example of a Trading Post in Cembalo: 1345-1476)]. Tavricheskie Studii. Istoricheskie nauki, 2015, vol. 7, pp. 12-18.

2. Antonin, arkhimandrit. Drevnie akty Konstantinopolskogo patriarkhata, otnosyashchiesya $\mathrm{k}$ Novorossiyskomu krayu [The Ancient Acts of the Patriarchate of Constantinople, Relating to the New Russian Region]. Zapiski Odesskogo obshchestva istorii i drevnostey, 1866, vol. VI, pp. 445-474.

3. Bayer G.-V. Metropolii Hersona, Sugdei, Gotii i Zihii po dannym prosopograficheskogo leksikona vremeni Paleologov [Metropolitan Kherson, Sougdea, Gothia and Zikhia according to the Data of the Prosopographic Lexicon of the Time of Paleologs]. Antichnaya drevnost i Srednie veka, 1995, vol. 27, pp. 65-76.

4. Berthier Delagarde A.L. Issledovanie nekotorykh nedoumennykh voprosov srednevekovya v Tavride [Study of Some Unclear Questions of the Middle Ages in Taurida]. Izvestiya Tavricheskoy uchenoy arkhivnoy komissii, 1920, vol. 57, pp. 1-136.

5. Bogdanova N.M. Kherson v X $-X V$ vv. Problemy istorii vizantiyskogo goroda [Cherson in the $10^{\text {th }}-15^{\text {th }}$ Centuries. Problems of the History of the Byzantine City]. Karpov S.P., ed. Prichernomorye $v$ Srednie veka [Black Sea Region in the Middle Ages]. Moscow, MGU Publ., 1991, vol. 1, pp. 8-172.

6. Bocharov S.G. Arkheologicheskie issledovaniya srednevekovogo zamka Gelin-Kaya v 2006 godu [Archaeological Research of the Medieval Gelin-Kaya Castle in 2006]. Stashenkov D.A., ed. Aktualnye voprosy arkheologii Povolzhya. K 65-letiyu studencheskogo arkheologicheskogo kruzhka Kazanskogo universiteta [Current Questions of Archaeology of the Volga Region. To the $65^{\text {th }}$ Anniversary of the Student Archaeological
Club of Kazan University]. Kazan, II AN RT Publ., 2012, pp. 109-121.

7. Bocharov S.G. Arkheologiya Latinskoy Gazarii: opredelenie termina i nauchnoe soderzhanie [Archaeology of Latin Gazaria: Definition and Content]. Kradin N. N., Sitdikov A. G., ed. Trudy III Mezhdunarodnogo kongressa srednevekovoy arkheologii evraziyskikh stepey «Mezhdu Vostokom i Zapadnom: dvizhenie kultur, tekhnologiy i imperiy» [Proceedings of the $3^{\text {rd }}$ International Congress of Medieval Archeology of the Eurasian Steppes "Between East and West: the Movement of Cultures, Technologies and Empires"]. Vladivostok, Dalnauka Publ., 2017, pp. 57-63.

8. Bocharov S.G. Genuezskie vladeniya v Krymu vo vtoroy polovine XIV v. [Genoese Domain in the Crimea in the Second Half of the $14^{\text {th }}$ Century]. Bylye gody, 2015, vol. 38-1, pp. 808-824.

9. Bocharov S.G. Zametki po istoricheskoy geografii Genuezskoy Gazarii XIV-XV vekov. Konsulstvo Soldayskoe [Notes on the Historical Geography of Genoese Gazaria of the $14^{\text {th }}-15^{\text {th }}$ Centuries. Consulate of Soldaya]. Antichnaya drevnost i srednie veka, 2005, vol. 36, pp. 282-294.

10. Bocharov S.G. Zametki po istoricheskoy geografii genuehzskoy Gazarii XIV-XV. Konsulstvo Chembalskoe [Notes on the Historical Geography of Genoese Gazaria in the $14^{\text {th }}-15^{\text {th }}$ Centuries. Consulate of Chembalo]. Povolzhskaya arkheologiya, 2017, vol. 2, pp. 204-223.

11. Bocharov S.G. Zametki po istoricheskoy geografii Genuezskoy Gazarii XIV-XV vv. Yuzhnyy bereg Kryma [Notes on the Historical Geography of the Genoese Gazaria in the $14^{\text {th }}-15^{\text {th }}$ Centuries. The South Coast of Crimea]. Myts V. L., ed. O drevnostyakh Yuzhnogo berega Kryma i gor Tavricheskikh: sb. nauch. tr. po materialam konf. $v$ chest 210-letiya so dnya rozhdeniya P.I. Keppena [On the Antiquities of the Southern Coast of the Crimea and the Tauride Mountains: Collected Academic Works Based on the Materials of Conference in Honour of the $210^{\text {th }}$ Birth Anniversary of P.I. Keppen]. Kiev, Stilos Publ., 2004, pp. 186-205.

12. Bocharov S.G. Istoricheskaya geografiya Genuezskoy Gazarii [Historical Geography of the Genoese Gazaria]. Bocharov S.G., Sitdikov A.G., ed. Dialog gorodskoy $i$ stepnoy kultur na Evraziyskom prostranstve. Istoricheskaya geografiya Zolotoy Ordy: materialy VII Mezhdunar. konf., posvyashch. pamyati G.A. Fedorova-Davydova [Dialogue of Urban and Steppe Cultures in the Eurasian Space. Historical Geography of the Golden Horde: Materials of the $7^{\text {th }}$ InternationalConference in Memory of G.A. FedorovDavydov]. Chisinau, Stratum plus Publ., 2016, pp. 263-269.

13. Bocharov S.G. Predvaritelnye rezultaty arkheologicheskogo issledovaniya ukrepleniya 
Uchansu-Isar [Preliminary Results of the Archaeological Excavation of the Wuchang-Isar Castle]. Bocharov S.G., Kozhokaru V., eds. Vzaimootnosheniya Severnogo i Zapadnogo Prichernomorya $v$ antichnuyu epokhu $i$ srednevekovye [Relations between the Northern and Western Black Sea Coast in the Ancient Era and the Middle Ages]. Simferopol, Izd-vo Baranovskogo, 2009, pp. $108-114$

14. Veymarn E.V. O dvukh neyasnykh voprosakh srednevekovya yugo-zapadnogo Kryma [About Two Unclear Questions of the Middle Ages of the SouthWestern Crimea]. Dombrovskiy O.I., ed. Arkheologicheskie issledovaniya srednevekovogo Kryma [Archaeological Research of the Medieval Crimea]. Kiev, Naukova dumka Publ., 1968, pp. 45-82.

15. Karpov S.P. Italyanskie morskie respubliki i Zolotaya Orda. Krizis 1343-1349 gg. [The Italian Maritime Republics and the Golden Horde. The Crisis of 1343-1349]. Karpov S. P., ed. Prichernomorye v Srednie veka [Black Sea Region in the Middle Ages]. Moscow, MGU Publ., 2015, vol. 9, pp. 7-42.

16. Kulakovskiy Yu.A. Proshloe Tavridy. Kratkiy istoricheskiy ocherk [The Past of Taurida. A Brief Historical Essay]. Kiev, V.I. Kulzhenko Publ., 1914. 154 p.

17. Lebedev A.P. Istoricheskie ocherki sostoyaniya Vizantiysko-vostochnoy tserkvi ot kontsa $X I$ do serediny XV veka [Historical Notes of the State of the Byzantine-Eastern Church from the End of the $11^{\text {th }}$ Century to the Middle of the $15^{\text {th }}$ Century]. Saint Petersburg, Aleteya Publ., 1998. 383 p.

18. Mejendorf I., archpriest. Vizantiya $i$ Moskovskaya Rus: ocherk po istorii tserkovnykh $i$ kulturnykh svyazey $v$ XIV veke [Byzantium and Moscow Russia: An Essay on the History of Church and Cultural Relations in the $14^{\text {th }}$ Century]. Paris, YMCA-PRESS, 1990. 227 p.

19. Myts V.L. Kaffa i Feodoro v XV veke. Kontakty $i$ konflikty [Caffa and Theodoro in the $15^{\text {th }}$ Century. Contacts and Conflicts]. Simferopol, Universum Publ., 2009. 528 p.
20. Myts V.L. Neskolko zametok po epigrafike srednevekovogo Kryma [A Few Notes on the Epigraphy of the Medieval Crimea]. Tolochko P.P., ed. Vizantiyskaya Tavrika [Byzantine Tavrika]. Kiev, Naukova dumka Publ., 1991, pp. 179-193.

21. Romanchuk A.I. Khersones XII-XIV vv. Istoricheskaya topografiya [Chersonesus in the $12^{\text {th }}-$ $14^{\text {th }}$ Centuries. Historical Topography]. Krasnoyarsk, Krasnoyarsk University Publ., 1986. 192 p.

22. Tizengauzen V.G. Sbornik materialov, otnosyashchikhsya $k$ istorii Zolotoy Ordy [Collected Materials on the History of the Golden Horde]. Saint Petersburg, Izd-vo Imp. Akad. nauk, 1884, vol. 1.559 p.

23. Yakobson A.L. Srednevekovyy Khersones $\left(X I I-X I V v v\right.$.) [Medieval Chersonesus $\left(12^{\text {th }}-14^{\text {th }}\right.$ Centuries)]. Moskva, Leningrad, AN SSSR Publ., 1950. $255 \mathrm{p}$.

24. Balard M. La Romanie Génoise (XIIe-début du XVe siècle). Roma, Genova, école Fran ${ }^{\circ}$ aise de Rome, 1978, vol. 1.494 p.

25. Basso E. Il "bellum de Sorchati" ed i trattati del 1380-1387 tra Genova e l'Ordo d'Oro. Studi genuensi. Nova Seria. 1991, vol. VIII, pp. 11-26.

26. Darrouzés J. Les regestes des actes du Patriarcat de Constantinople. Les actes de Patèriarches. Las regestes de 1377 a 1410. Paris, Institut fran ${ }^{\circ}$ ais d'études byzantines, 1979, vol. I. Fasc. VI. $548 \mathrm{p}$.

27. Fisher A. The Ottoman Crimea in Sixteenth Century. Harvard Ukrainian Studies, 1981, vol. V, no. 2, pp. 135-170.

28. Miklosich F., Müller J. Acta et diplomata graeca medii aevi sacra et profana. Vindobonae, Carolus Gerold, 1860, vol. I. 543 p.

29. Skrzinska E. Inscriptions latines des colonies génoises en Crimée. Genova, Atti della Societa Ligure di Storia Patria, 1928, vol. LV1. 141 p.

30. Veinstein G. La population du Sud de la Crimée au début de la domination Ottomane. Bulletin de Institut fran ais d'études anatoliennes. Mémorial Ömer Lûtfi Barkan, 1980, fis. XXVIII, pp. 227-249.

\section{Information about the Author}

Sergey G. Bocharov, Candidate of Sciences (History), Senior Researcher, Department of Medieval Archaeology, Institute of Archaeology of the Crimea of RAS, Yaltinskaya St., 2, 295007 Simferopol, Russian Federation, sgbotcharov@mail.ru, http://orcid.org/0000-0003-4775-4136

\section{Информация об авторе}

Сергей Геннадиевич Бочаров, кандидат исторических наук, старший научный сотрудник отдела средневековой археологии, Институт археологии Крыма РАН, ул. Ялтинская, 2, 295007 г. Симферополь, Российская Федерация, sgbotcharov@mail.ru, http://orcid.org/0000-0003-4775-4136 